\title{
Attacking Democracy through Immigration Workplace Raids
}

\author{
Bill Ong Hing
}

\section{Introduction}

On a cold, raw December morning in Marshalltown, Iowa, Teresa Blanco woke up to go to work at the local Swift meat packing plant. Hundreds of others across the town were doing the same thing, in spite of the miserable mixture of sleet, mist, and slush that awaited them outside their front doors. As they made their way to the plant, the workers, who were from Mexico, did not mind the weather.

Unfortunately, the workers' day turned into a nightmare soon after they reported for work. Not long after the plant opened, heavily armed agents from the U.S. Immigration and Customs Enforcement agency ("ICE") stormed onto the scene. Pandemonium broke out. The workers panicked; many began to run; others tried to hide, some in dangerous and hazardous areas. As the ICE agents began rounding up all the workers, they ordered those who were U.S. citizens to go to the cafeteria. Noncitizens were directed to a different section of the plant. Agents shouted out instructions: documenteds in one line, undocumenteds in another. If an agent suspected that the person in the documenteds' line was undocumented, the agent would instruct the person to get into the undocumented line. More than one individual was told, "You have Mexican teeth. You need to go to that line [for undocumented persons] and get checked." (National Commission on ICE Misconduct \& Violations of Fourth Amendment, Commission Hearing: Des Moines, Iowa, 2008)

The nightmare was only beginning. Although supervisory Immigration and Customs Enforcement (ICE) agents carried a civil warrant for a few individuals, the squad demanded that all plant employees be held, separated by nationality. That included U.S. citizen workers who were interrogated and detained. No one was free to leave - not even those who carried evidence of lawful status or proof they were in the process of seeking proper permission to be in this country. Each was interrogated individually. The process took the entire day, and phone calls were not permitted until later in the day. By the end of the day, 90 were arrested, but hundreds, including citizens, had been detained for hours (Ibid.) The entire community was shaken to its core.

The Marshalltown raid was one of the more egregious operations under the George W. Bush administration, conducted not long after his push for immigration reform in 2004.

Although, Barack Obama's administration focused more on "silent raids" of I-9 audits instead of armed operations, the Donald Trump administration picked up right where the Bush administration left off (Bacon and Hing 2010). Armed workplace raids by Immigration and Customs Enforcement agents were instituted again soon after Donald Trump took office. The Trump ICE raid that received the most notoriety took place on August 7, 2019, when almost 700 workers were arrested at food processing plants in central Mississippi. Those arrested included two single mothers - each with three minor children - whose children had to be cared for by friends or other family members. A breastfeeding mother was separated from her 4-month old baby. Video and photos posted after the initial stages of the raid showed men and women 
walking in boots with their hands zip-tied behind their backs. Other detained employees sat on the grass or near large, white silos on the company property. Neighbors worried about a 12-yearold girl whose mother was being questioned by officers inside the plant. A girl could be heard wailing in the background. A girl no more than three feet tall slowly waddled toward the metal gate to look, with other workers, at those who were being detained.

I had the opportunity to learn more about the effects of several Bush ICE raids first hand as part of a commission that was established by the United Food and Commercial Workers International Union ("UFCW") in 2008. The Commission spent more than a year holding regional hearings, interviewing witnesses, and soliciting input from a wide range of workers, elected officials, policy experts, psychologists, and religious and community leaders.

Commissioners learned about the abuse that ICE officials visited upon workers, their families, and the communities.

Analysis of workplace ICE raids expose racial profiling and the attendant trauma to children and families as well as social and economic damage to communities. However, the manner and timing of these raids also represents an attack on democracy that we should not ignore. The raids come at a time when immigrants are playing a vital role in the labor movement.

ICE raids challenge us to think seriously about the underlying implications of those raids. The tragic effects on families and communities, as well as the serious constitutional violations committed by ICE agents during the raids, provide ample moral and legal justification to end the raids. However, the inherent racism at the center of the ICE raids and other ICE and Border Patrol operations raises further concern that receives little public attention. With few exceptions, the ICE operations target Latinx--usually Mexicans. Suppression of the labor movement, racism, violation of constitutional rights, and toleration of a subaltern class of exploited workers who have no right to participate in government are, separately and even more so together, inconsistent with democratic governance.

The structure of immigration laws has institutionalized a set of values that dehumanize, demonize, and criminalize immigrants of color. The result is that these victims stop being Mexicans, Latinx, or Chinese and become "illegal immigrants." We are aware of their race or ethnicity, but we believe we are acting against them because of their status, not because of their race. This institutionalized racism makes the Bush and Trump ICE raids natural and acceptable in the minds of the general public. Institutionalized racism allows the public to think ICE raids are freeing up jobs for native workers without recognizing the racial ramifications. Objections to ICE raids are debated in non-racial terms. Failing to recognize these operations from the perspective of institutional racism is problematic, of course. But ignoring how raids inhibit labor organizing and constitute an attack on democracy also is a problem.

While workplace raids are emblematic of blatant and structural racism, workplace raids are blatantly anti-democratic: ignoring the Fourth Amendment during raids, violating civil rights, engaging racial profiling, and disrupting labor organizing. In short, democratic principles are jeopardized. Given the American labor movement's shift toward including noncitizen workers, the attack on such workers is properly viewed as an attack on the labor movement.

\section{Entering the ICE Age of Enforcement}

The ICE age of immigration enforcement began when Department of Homeland Security ("DHS") was established in 2003. The new DHS took over the old Immigration and Naturalization Service ("INS") from the Department of Justice. Repackaged, interior 
enforcement functions were channeled into ICE.

Immigration raids, including worksite operations, have been part of immigration enforcement for decades. However, the courts had placed constraints on INS and Border Patrol agent activities during raids. For example, in INS v. Delgado, although the U.S. Supreme Court did not find the particular worksite operation in question unconstitutional, the Court held that without a warrant INS agents cannot seize an entire worksite, workers have the right to remain silent, and workers can leave if agents have no reasonable suspicion that the workers are unauthorized to be in the United States. ${ }^{1}$

But in January 2004, after Republicans showed little interest in a guest worker proposal, Bush implemented the current ICE raid strategy to garner support for his plan. His detractors on the right argued the proposal was too lenient and amounted to amnesty. Bush responded with a strong enforcement program. In the process, ICE agents ignored the legal constraints that had been imposed on the old INS raids. The actions suggested that the well-established rules were no longer applicable to the new DHS. Homeland Security Secretary Michael Chertoff and ICE Assistant Secretary Julie Myers ushered in the new ICE age seemingly free of the old constraints.

\section{The Swift Raids}

Early on the morning of December 12, 2006, the feast day of Our Lady of Guadalupe and a holy day of special significance to Catholics of Mexican descent, ICE conducted a massive military style raid on six Swift \& Company meatpacking plants across the nation's heartland. Hundreds of federal agents in riot gear, armed with assault weapons, descended upon plants in Cactus, Texas; Greeley, Colorado; Grand Island, Nebraska; Worthington, Minnesota; Marshalltown, Iowa; and Hyrum, Utah.

ICE was there to execute arrest warrants for a handful of named workers - less than one percent of the workforce. The sheer number of ICE agents on the scene and the manner in which the operation was conducted made clear that the execution of those warrants was not the government's real purpose. Rather, the raids seemed designed to ramp up the number of arrests and capture the headlines on the evening news. ICE rounded up nearly 13,000 workers - the vast majority of them U.S. citizens - holding them against their will for hours.

According to witness testimony, there were, perhaps, 100 people standing at the fence in front of the Marshalltown plant by the end of the day. Many were people who had family members working the first shift.

While Sister Christine, a Catholic nun, and family members held vigil outside, the workers inside were caught in a frightening, military-style assault. Instead of searching out the 133 individuals named on the arrest warrants, heavily armed ICE agents fanned out through each of the affected plants, sealed the exits, and ordered workers into lines where they were patted down and searched for weapons. After the weapons search, ICE agents herded workers en masse into the plant cafeterias or other holding areas and divided them by race and national origin. Many were denied food, water, or the use of bathroom facilities; some were handcuffed. No one was advised of their rights or provided access to legal representation at the raid site. The overwhelming majority of those held that day were U.S. citizens. In Marshalltown, Michael Graves, a U.S. citizen, got to work that morning and was instructed to go to the cafeteria.

\footnotetext{
${ }^{1}$ Immigration \& Naturalization Service v. Delgado, 466 U.S. 210 (1984).
} 
[Heavily-armed] ICE agents . . . questioned me about my status as a U.S. citizen and I said my mother and father were born and raised in Mississippi. He questioned me about that and asked me, did I know my route to Mississippi? And I said no, but I can find my way there because I had been there a lot of times with my parents. He looked at my I.D. again, told me to sit down with my hands behind my back, still handcuffed. (United Food and Commercial Workers Union. 2009)

Graves was forced to sit in that position for over an hour. ICE continued to hold him and coworkers - still deprived of food, water, and external communication - until he was finally released after eight hours of captivity and told to "go home."

Another U.S. citizen, Melissa Broekemeier, had worked at the Swift plant in Marshalltown for more than eight years. But the "longest day [she] ever worked was on December 12, 2007." Broekemeier described her experience on the day of the Swift raid this way:

I, like all my coworkers that went to work that day ... we were instructed by our supervisors to finish up ... and report to the cafeteria, where we were inspected, and our private lives were scrutinized by ICE agents as if we were illegal convicts . . . . The power that runs our machines should have been shut off first, but it was not . . . The Federal government jeopardized our safety and health without care. We were overlooked. We were ignored. We were treated like criminals. We were not free to leave. ... We had people who really lost control, we had people rolling on the floor . . . upset and distressed. They really lost their dignity ... (National Commission on ICE Misconduct \& Violations of Fourth Amendment, Commission Hearing: Des Moines, Iowa, 2008)

During their interviews with ICE agents at the plant, the alleged undocumented workers were asked if they had children, but were not told that one of the parents would be allowed to remain to care for them. Many parents were afraid to say "yes" because they feared their children would be taken away from them and placed in foster care. In one case, a six-year-old and twoand-a-half-year-old stayed with a babysitter for three weeks until the mother was deported. In another family, an elderly woman had been living with her daughter. The daughter was detained, and the mother spoke no English, did not drive, and was not familiar with Marshalltown.

Immigrant rights attorney, Sonia Konrad, concluded that the ICE agents "conducted themselves as if they were dealing with terrorists entering the premises in uniform, black jackets, strapped down guns, shouting and leaving no doubt to all workers that . . . they were not free to go." (Ibid) ICE made sure that people were uprooted and moved out of Iowa quickly, some of them within twenty-four hours of their arrests and detention. Once arrested, people were coerced into signing stipulated orders of deportations without an opportunity to consult with an attorney. Konrad and her colleagues were relegated to quickly writing powers of attorneys and guardianships for those detainees.

\section{Other Raids}

1. Stillmore, Georgia 
One ICE raid in Stillmore, Georgia, the Friday before Labor Day weekend in 2006, evoked outcry from local residents who labeled the ICE action as nothing short of "Gestapo tactics." Descending shortly before midnight, ICE agents swarmed the area, eventually arresting and deporting 125 undocumented workers. Most of those rounded up were men, while their wives fled to the woods to hide children in tow. In the weeks after the raid, at least 200 more immigrants left town. Many of the women purchased bus tickets to Mexico with their husband's final paycheck. The impact underscored how vital undocumented immigrants were to the local economy. Trailer parks lay abandoned. The poultry plant scrambled to replace more than half its workforce. Business dried up at stores. The community of about a thousand people became little more than a ghost town. The operator of a trailer park that was raided, David Robinson, commented, "These people might not have American rights, but they've damn sure got human rights. There ain't no reason to treat them like animals." (Bynum, 2006)

Local residents witnessed the events, as ICE officials raided local homes and trailer parks, forcing many members of the community out of Stillmore. Officials were seen stopping motorists, breaking into homes, and there were even reports of officials threatening people with tear gas. Witnesses reported seeing ICE officials breaking windows and entering homes through floorboards. Mayor Marilyn Slater commented, "This reminds me of what I read about Nazi Germany, the Gestapo coming in and yanking people up." (Bynum 2006)

\section{San Rafael, California}

On March 6, 2007, ICE officials raided the small communities of San Rafael and Novato in Marin County, arresting roughly 30 undocumented immigrants. This raid was also part of ICE's "Operation Return to Sender," the federal effort to crack down on immigrants who have stayed past their deportation orders. ICE officials armed with warrants bearing dated and/or incorrect information stormed homes and began arresting violators regardless of whether they were named in the original warrant. The San Rafael raid became a national symbol of the traumatic effects raids have on children. Juan Rodriguez, principal of Bahia Vista Elementary School, noted that on a typical day the school might have eight to ten children absent, but 77 children were absent the day of the raid. San Rafael's Mayor Alberto Boro criticized federal officials, noting that the raid resulted in a drop in calls to local law enforcement agencies, signaling a heightened level of mistrust of police within the community.

\section{New Bedford, Massachusetts}

In March 2007, nearly 500 ICE officials descended upon the small southern New England community of New Bedford, Massachusetts. ICE officials targeted the local Michael Bianco, Inc. plant, a leather goods manufacturer that had manufactured goods for brands such as Coach, Rockport, and Timberland. As with other larger raids, the event split families and underscored the negative effects the raids have on communities. Because many of Bianco's employees were women, this created a crisis with caring for their children. Roughly 100 children were stranded with babysitters and other caregivers as their mothers were seized during the raid. The majority of those arrested were moved to detention centers halfway across the country in Texas.

4. Postville, Iowa 
One of the largest immigration raids in U.S. history occurred in April 2008 in the small, Midwest town of Postville, Iowa. The raid occurred at the kosher meat plant, Agriprocessors, Inc., the largest employer in town and one of the largest in northeastern Iowa. ICE seized over 400 undocumented workers, including eighteen juveniles.

Agriprocessors employed approximately 970 workers, eighty percent of whom were believed to have fraudulent identification. After the raid, the entire Postville community was in recovery mode. Mayor Robert Penrod speculated on the effect of a possible Agriprocessor closure, estimating that "two-thirds of the homes here will sit empty [and] 95\% of downtown business . . . will dry up." One witness labeled the government strategy "criminal" as hundreds of women and children were faced with the threat of being left "homeless and starving." (Newman 2008)

As in other communities, the school system also felt the immediate impact of the raids. The local school district estimated that 150 of the 220 students from immigrant families were absent the day after the raid.

\section{Northern California Chinese Restaurants}

On September 17, 2008, ICE special agents executed federal criminal search warrants at four sites in the northern California towns of Vacaville, Vallejo, and Hercules, in the North Bay area northeast of San Francisco, as part of an investigation into the hiring and possible harboring of unauthorized workers at local Chinese restaurants. ICE agents made no criminal arrests but arrested 21 workers on administrative immigration violations. The arrested workers were from five countries: nine from China, five from Mexico, three from Guatemala, two from Indonesia, one from Singapore, and one from Honduras.

\section{Racial Profiling}

The United Food and Commercial Workers Commission that I was on heard repeated testimony about racial profiling. Witnesses testified that workers who appeared to be of Latinx national origin or minorities were singled out by ICE and subjected to the greatest scrutiny. John Bowen, General Counsel for UFCW Local 7, said "race was, almost without question, the sole criteria for harsher interrogations" to which the workers were subjected at the Greeley, Colorado plant. Fidencio Sandoval, a U.S. citizen and Swift worker at the Grand Island, Nebraska, plant, recounted how he was released only after his sister was able to go to his home, "break the window from my kitchen and go straight to my closet and get my citizen certificate." (National Commission on ICE Misconduct \& Violations of Fourth Amendment, Commission Hearing: Des Moines, Iowa, 2008)

Other U.S. citizen coworkers were not as fortunate. Those who did not have a way to prove their citizenship were arrested and taken to Camp Dodge, located nearly 300 miles from Grand Island. Manuel Verdinez was finally release after twelve hours. "They called a cab for me and I had to pay $\$ 90$ for the cab ride back." (National Commission on ICE Misconduct \& Violations of Fourth Amendment, Commission Hearing, Boston (2008)

The increased racial profiling and selective enforcement is also evident in the manner in which local police enforce immigration law pursuant to section $287(\mathrm{~g})$ of the Immigration and 
Nationality Act. ${ }^{2}$ In Nashville, Tennessee, a police officer pulled over Juana Villegas, who was nine months pregnant at the time, for a routine traffic violation. The arrest was made pursuant to a section $287(\mathrm{~g})$ agreement and resulted in Villegas' detention in county jail. According to the New York Times, Villegas went into labor and delivered her baby with a "sheriff"s officer standing guard in her hospital room, where one of her feet was cuffed to the bed most of the time." (Preston, 2008) Although the Obama administration severely reduced and more carefully controlled 287(g) agreements with state and local law enforcement agencies, the Trump administration reinstated the 287(g) program with full force (Pham 2018). More than 140 jurisdictions across 20 states currently have 287(g) agreements (Dinan 2020).

\section{Damage to Communities}

ICE raids and increased enforcement have caused severe social and civic damage and major setbacks for many communities. In Iowa, communities had developed several successful initiatives designed to stimulate the assimilation of immigrants into the fabric of the communities where they resided. Great progress toward integration and understanding had taken place in Marshalltown. But the ICE raid undid much of that progress. The raid had given some members of the community "a justification for discriminating against all immigrants, documented or not."

Raids also hurt local economies. Jorge Avellanada, city council member and a business leader in Chelsea, Massachusetts, told the Commission that the raids resulted in a thirty percent decline in sales due in part to the fear that workers had about going to work, shopping, or going about their normal business.

The negative ramifications of the raids on communities manifest themselves in other ways. Increased enforcement and high profile military-style raids have resulted in the immigrant community being afraid to report abuse or crime for fear of being turned over to ICE. However, workplace raids also disrupt labor organizing directly and has a chilling effect on union participation.

\section{Effect on the Labor Movement}

At the height of the American labor movement in the 1950s, more than a third of American workers were union members (Figueroa 2019). However, today only 10.5 percent of workers are union members - the lowest unionization rate among wealthy nations.

Federal actions contributed to the decline. For example, the Taft-Hartley Act of 1947 restricted unions and hampered organizing efforts by facilitating state right-to-work laws allowing nonunion members to enjoy union benefits without paying dues. President Reagan sharpened the assault with new regulations. In 1981, he fired 11,000 striking air traffic controllers who refused his back-to-work order after they walked out to protest poor working conditions and low pay. A 2018, Supreme Court case created a major hurdle ruling that state governments cannot force public employees who do not join unions to pay fees that support

2 Title 8, United States Code, Section 1357(g) 
collective bargaining. ${ }^{3}$ More than 20 states had required these fair-share fees (Figueroa 2019).

Besides those real challenges, some labor leaders understand that the tough work of organizing, convincing members to expand ranks, and putting more resources toward those efforts have been neglected. One union that understands, the Service Employees International Union (SEIU), now spends 20 percent of its budget to bring in workers who are not already union members. (Figueroa 2019) Its strategy has paid off, as its membership increased by adding immigrant workers. (Figueroa 2019)

The key to SEIU's growth — and that of other expanding unions - is a focus on immigrant workers, including those workers without employment authorization. Historically, many rankand-file union members had problems with undocumented workers, perhaps with good reason. Developers and construction companies often turned to an undocumented workforce to undercut union costs. A stark example is Donald Trump's real-estate company that, in 1980, recruited 200 undocumented Polish workers to demolish the Bonwit Teller building to clear ground for the 58story Trump Tower. The workers - some of whom were only paid $\$ 4$ an hour-worked 12-hour shifts, without basic safety on very dangerous work (Hennelly 2019). Management also exploited racial division and anti-immigrant sentiment in this arena. The tactic pitted one group against another, often establishing a "certain color hierarchy and class pecking order" (Hennelly 2019).

Many labor activists recognize that the future of their movement depends on incorporating immigrants. For them, this is about survival - not just about social justice on behalf of workers. They are relying on the basic tenet of the labor movement - a collective effort to empower workers irrespective of background. Often, union members are placed on job sites to work alongside undocumented workers. The unions realize that aside from safety concerns, the immigrant workers face other challenges, such as immigration, housing, and health. Those are matters that the union can help address.

Labor leaders increasingly see alignment with immigrant workers as an opportunity. When Trump unveiled a plan to penalize noncitizens for using government assistance, New York Attorney General Letitia James filed a lawsuit opposing the move. A big part of a crowd cheering her on were members of 1199 SEIU, the nation's largest health care union (Hennelly 2019).

Low-wage workers from Mexico and Central America are at the center of the efforts to rebuild the U.S. labor movement. Not only have they been the focus of this dynamic effort, but the immigrant workers themselves are on the front lines of worker center organizing and advocacy efforts. This has occurred in parallel with a vibrant immigrant rights movement, which combines civil rights and labor rights elements. The work has infused the U.S. labor movement with new energy, new tactics, and new ideas (Milkman 2009).

The mutual attraction between labor and migrant workers is obvious. Low-wage and working-class immigrants come to the United States with dreams of economic advancement, but they arrive with few resources. They are often confined to the bottom of the labor market, where wages are low, working conditions poor, benefits are limited, and chances for promotion extremely restricted. Many immigrants are concentrated in job segments where wage theft and other labor law violations are prevalent. This abuse and lack of resources makes the labor movement appealing to low-wage immigrants. And even though many such workers lack legal status, much of the wider public is sympathetic when their abuse is highlighted. (Milkman 2009).

Foreign-born workers make up 17.5 percent (29 million) of the nation's 165 million workers (Budiman 2020). Many are high-wage earners, including professionals and

\footnotetext{
${ }^{3}$ Janus v. AFSCME, 138 S.Ct. 2448 (2018).
} 
entrepreneurs. More than a quarter (7.6 million) are not authorized to work, most of them Latinx (Budiman 2020). They typically hold low-wage jobs in agriculture, construction, food and garment manufacturing, hotels and restaurants, and low-wage service industries. Many noncitizens with lawful permanent or refugee status are also employed at or near the bottom of the labor market. Others hold jobs with better pay and conditions. That possibility motivates many at the low end to join the new immigrant labor movement (Milkman 2009).

Traditional trade unionism is important to the immigrant labor movement today. In spite of the fact that many unions supported restrictive immigration policies historically, beginning in the 1980s, several leading unions began to organize Latinx immigrants employed in low-wage sectors, including janitorial, retail, hospitality, residential construction, and manufacturing. In 2000, the AFL-CIO supported legislation that would have granted legalization to undocumented workers. Although immigrant union organizing is uneven across industries and occupations, today virtually all U.S. labor unions offer at least some support for immigrant workers (Milkman 2009).

When labor organizers first began recruiting more immigrant workers in the 1980 s, many movement officials were skeptical that the workers would be receptive. Why would workers who intended to return home after earning a certain amount invest time and effort into organizing? Furthermore, the low wages here were still probably better than what the workers made back home. Would they really be concerned about raising U.S. labor standards? Organizers assumed that immigrants unauthorized to work would worry about apprehension and deportation if they became active in unionization (Milkman 2009).

However, countervailing factors actually made organizing Latinx immigrant workers easier than expected. Immigrant social networks that help newcomers adjust and find jobs can be strong. Those social networks become a resource for union organizing. Latinx immigrants also have a sophisticated worldview of how their individual fate is tied to that of their community as a whole. Collective action is viewed as an opportunity for community advancement. And some of the workers also have backgrounds in political and/or union activism in their home countries (Milkman 2009). The communal experience that many Latinx workers endure in being subordinated for lacking immigration documents creates an open-mindedness toward organizing efforts. The shared stigmatization creates a natural comradery. Also, any fear related to participating in unionization efforts pales in comparison with crossing borders or living under threat of immigration enforcement. Still, like most American workers, the vast majority of immigrant workers are not part of organized labor (Milkman 2009). ${ }^{4}$

The matter of organizing immigrant workers invariably raises the effect of the 2002 U.S. Supreme Court's ruling in Hoffman Plastic Compounds, Inc. v. National Labor Relations Board. ${ }^{5}$ In an earlier case, Sure-Tan, Inc. v. National Labor Relations Board, the Supreme Court held that immigrant workers without work authorization are still protected by the National Labor Relations Act. ${ }^{6}$ It is an unfair labor practice for an employer to report such workers to immigration authorities in retaliation for engaging in union activities. But in Hoffman, the Court held that if unauthorized immigrant workers are fired improperly for organizing activities, they are not entitled to back pay or reinstatement (the legal remedies available to workers under the

\footnotetext{
${ }^{4}$ Recent surveys indicate that 64 percent of Americans approve of unions, much higher than during the Great Recession more than a decade ago. (Jones 2019)

${ }^{5}$ Hoffman Plastics Compounds, Inc. v. NLRB, 535 U.S. 137 (2002).

${ }^{6}$ Sure-Tan Inc. v. NLRB, 467 U.S. 883 (1984).
} 
NLRA). However, the impact of Hoffman may be less significant than originally feared because remedies all workers under the NLRA have been curbed (Garcia 2012: 669-70).

In spite of the Hoffman decision and the fact that workers without immigrant documents are denied many basic civil rights, in principle they still are protected by nearly all laws covering wages, hours, and union representation. The basic principles of the earlier Sure-Tan decision still stand. Since all workers regardless of immigration status are protected under the NLRA, the broader purpose of the labor movement to have all workers represented remains legitimate (Milkman 2009).

Of course, serious challenges persist for immigrant workers. All workers have witnessed an erosion of employment and labor laws over the past few decades. At the same time, punitive immigration laws have increased along with enforcement strategies like the workplace raids. Low-wage immigrant workers are more vulnerable, as deportation enforcement renders employment and labor law meaningless for those who are removed (Milkman 2009).

After 9/11, the prospects for immigration reform that would include legalization for undocumented immigrants faded. President Bush tried to get immigration reform talks started again by putting forward a large guest worker plan. But the plan got push back from both the right and the left (Hing 2006). So the Bush administration turned its enforcement attention to a new strategy.

The tragic events of 9/11 led to the profiling of Arabs, Muslims, and Sikhs in America. But anti-immigrant forces took advantage of the events to focus on other noncitizens as well. In response to those pressures and perhaps also in response to the huge immigrant rights marches in the spring of 2006, the Bush ICE began to orchestrate the series of high-profile workplace raids discussed above (Milkman 2009). Immigration raids and deportations were by no means a new phenomenon, but the scale was unprecedented.

The raids created a climate of fear. As a result, immigrants without documents who experienced labor and employment law violations were even less likely to pursue whatever legal remedies that might be available, chilling participation in the labor movement (Milkman 2009).

\section{Ramping Up Under Trump}

The Trump administration's well-documented anti-immigrant agenda included the Bush era workplace raids playbook. The Mississippi raid that resulted in the arrest of almost 700 workers was one example. Although ICE took a pause when the Covid-19 pandemic first hit, ICE soon resumed its enforcement tactics. In a two-month period beginning in mid-July 2020, immigration agents arrested more than 2,000 people at their homes, workplaces, and other sites (Jordan 2020).

As enforcement resumed at the workplace, some U.S. unions saw an opportunity and responsibility; Trump's focus became a new battlefront between the Republican party and organized labor. Unions understand that ICE agents, the National Labor Relations Board, and the courts are firmly on the side of the rich and powerful. The labor movement understands that this is not simply organizing workers shop by shop. This is about the need for widespread efforts to mobilize large numbers of workers. This "big tent approach" calls for a deep understanding of the economics and competitive dynamics within industries, and unions can help address inequality, division, and attacks on democracy that Trump and his supporters have sowed (Figueroa 2019). 
This broader vision incorporates defending their membership facing immigration enforcement as well. Take the case of Hugo Mejía Murguía, an undocumented worker from northern California who got a call to report to work in May 2017. When he arrived Travis air force base in California, military police called ICE, suspicious his immigration status. ICE also detained a second worker, Rodrigo Núñez (Elk 2018). Hugo's union, the Painters Union Local 82 , hired a lawyer to represent him, and eventually he won political asylum. Rodrigo was less fortunate and was deported back to Mexico. Their different fates highlight the continuing split personality in the union movement and its attitude to undocumented workers. Rodrigo's union, the United Brotherhood of Carpenters, did not defend him (Elk 2018). The leadership of North America's Building Trades Unions has traditionally been one of the whitest sectors of the labor movement. However, over the last two decades as some construction unions sought to organize larger numbers of undocumented workers, the attitude of labor has slowly changed (Elk 2018).

Neidi Dominguez, a 30-year-old Mexican immigrant who lived in the United States without legal status until she was 25, is the Painters Union's national strategic campaign coordinator. As the first Latina woman to head a major department at the Painters Union, Dominguez has led efforts not only to make her union more vocal and active on immigration, but to push other unions to be more proactive. Dominguez understands that since the majority of new members in the construction workforce are Latinx, building trades unions must do more to embrace immigrant workers to survive. In response to the Trump administration enforcement focus on undocumented workers, the Painters Union is one of many that has become a "sanctuary union" and developed programs to defend their membership against the threat of deportation (Elk 2018).

A New York coalition of organized labor and immigrant rights advocates in New York also has emerged. In January 2019, both camps celebrated the passage of the state DREAM Act, which made undocumented immigrants eligible for in-state college tuition assistance. Months later, the state legislature authorized driver's licenses for undocumented immigrants, a critical measure for migrant workers. Then the legislature passed the landmark Farmworkers Fair Labor Practices Act, which focused on working conditions, overtime pay, a day off, unemployment benefits, and the right to organize (Hennelly 2019).

Make no mistake. Labor unions are playing defense following a string of adverse decisions from the U.S. Supreme Court and the National Labor Relations Board - both bolstered by Trump appointees - while right-to-work laws have decimated union membership in a number of states. However, an alliance between unions and immigrants offers a path forward. The relationship between immigrants and labor is important in the battle over how the United States chooses to define itself. The immigrants' rights movement has been lauded for its successful organizing models, often drawing upon the vitality and ingenuity of immigrant-based worker centers, which themselves have emerged as alternatives to traditional labor unions. (Rathod 2014). This collaboration is revitalizing the U.S. labor movement.

\section{Attack on Democracy During the Trump ICE Age}

Viewed as an assault on workers who represent the future of the American labor movement, workplace raids by ICE are aptly viewed as an attack on democratic attempts to advocate for workers' rights in the United States. Certainly, going through three versions of the Muslim ban before it passed constitutional muster, diverting billions from the Pentagon's budget to fund border wall construction, and using a faulty legal arguments to terminate DACA are 
emblematic of the Trump administration's disregard for the rule of law and democratic principles. However, specifically targeting workers without papers who are otherwise protected by the NLRA strikes at the heart of organizing efforts.

While difficult to quantify precisely, the election of Donald Trump "unleashed" ICE officers bent on greater enforcement who felt constrained under the Obama administration. Many ICE agents did not like the lenient prosecutorial discretion memos issued by the Obama administration; the ICE union unsuccessfully tried to sue the Obama administration over the DACA program, arguing that the deferred action program undermined their duty to enforce the law. The border patrol union threw its support behind candidate Trump during the 2016 primaries, stating that he would "embrace the ideas of rank-and-file Border Patrol agents" (Davidson 2016). Thus, many immigration agents welcomed Trump's enforcement regime. For example, consider the phenomenon of "collateral arrests" of non-criminals:

What distinguished last week's raids from the Obama era were three things: First, ICE agents broke with years of Obama-administration policy by making "collateral arrests" - arresting unauthorized immigrants who happened to be in the place they were raiding, even if they didn't have a warrant for them. Second, the agency deliberately coordinated a series of nationwide raids, scooping up more people in less time than ICE raids typically do.

In most cases, ICE agents weren't sweeping through whole neighborhoods or stopping drivers at random - but there wasn't anything stopping them from doing so, and no indication they won't start in future."

\section{(America’s Voice 2017)}

Critics of President Trump may focus on one or more substantive issues, such as the insurrection at the Capitol on January 6, 2021, racial justice, the environment, handling of the pandemic, the growing deficit, Russian interference in the election, the Emoluments Clause, and, of course, immigration policy. Like so many authoritarian rulers around the world, Trump engaged in an attack on the rule of law and essential democratic institutions. Like antidemocratic leaders around the world, Trump sought to undermine the free press and erode the independence of law enforcement and the judiciary (McMullin 2018). He called the press the "enemy of the American people," repeatedly labeled reputable media outlets as "fake news," and undermined media watchdogs (Feffer 2018).

We saw these strategies used repeatedly in the immigration realm. This began with Trump's claim that Barack Obama was not a U.S. citizen (repeated with a similar suggestion about Kamala Harris) and included his false assertions that "Mexico is sending us rapists and criminals," that asylum seekers approaching the U.S. southern border are terrorists, that people from "shithole" countries like Haiti and African did not deserve temporary protected status, and that sanctuary cities harbor dangerous felons. Trump was also quick to criticize federal judges who ruled against some of his immigration orders. For example, in the space of one week in 2017, President Trump belittled all four judges who ruled against him in separate lawsuits challenging his first Muslim travel ban. He referred to Judge James Robart, a George W. Bush appointee who temporarily suspended the travel ban, as a "so-called judge" whose decision was "ridiculous." When the case was heard by an appeals court panel, Trump told a group of police 
chiefs that even a "bad high school student" could understand the ban was authorized by law (Totenberg 2017). In fact, former Acting Attorney General Sally Yates was fired for refusing to defend Trump's first version of the "shameful and unlawful Muslim travel ban." She called Trump's decision to restrict travel to the United States from several majority-Muslim nations "the start of his relentless attacks on our democratic institutions and countless dedicated public servants" (Moreno 2020).

Perhaps the most blatant attack on the judiciary came on the heels of the Supreme Court's decision that the Trump administration's attempt to terminate the Deferred Action for Childhood Arrivals (DACA) program violated the Administrative Procedures Act. ${ }^{7}$ While the Court did not doubt that the administration had the authority to terminate DACA if done properly, its justification at that juncture constituted an "arbitrary and capricious" action. So the DACA program was reinstated by the Court. In spite of the Court's decision - and in a challenge to the fundamental principles of Marbury v. Madison - the Trump administration refused to adhere to the Supreme Court's authority, refusing to accept new DACA applications after the decision. A federal court subsequently had to order the administration to accept new applications (Rose 2020).

As underscored above, the Trump administration returned to using high-profiled, armed, physical raids. And early in his administration, it became clear that workplace raids was a big priority. ICE oversaw a massive surge in the number of workplace immigration raids in 2018, with more than four times the number of raids aimed at finding and arresting undocumented immigrants compared to the year before. Agents opened 6,848 worksite investigations in the fiscal year of 2018, compared to 1,691 investigations opened in 2017 (Mindock 2018).

The Trump assault also illustrates the vulnerability of undocumented workers. They become targets of ICE at times based on information that ICE has obtained from informants, employer records, or instincts of agents. Or they may be targeted by the employers themselves who may be threatened by organizing activity. A pattern between workers' labor activism and immigration enforcement has been documented, where employers actually call agents to act against workers who seem inclined to organize (Wishnie 2004).

These efforts are appropriately viewed as part of the Trump assault on democracy. The surge in workplace raids come at a time when unions are making outreach to undocumented workers a priority. Removing the workers strikes at the heart of the today's union movement.

\section{Contextualizing the Racialized Evolution of Immigration Laws and Workplace Raids}

The evolution of immigration policy, beginning with the forced migration of African workers through the infamous Asian exclusionary period and then to the southwest border regime, is critical in understanding today's policies and enforcement approaches. The history affects today's enforcement. And associated institutions exacerbate the effects of the racialized immigration system.

\section{From Dehumanization and Demonization to Criminalization}

The institutionalized racism of U.S. immigration laws and enforcement policies reflects the evolution of immigration laws that grappled with constant tension over who is and who is not acceptable as a true American. Early in U.S. history, preferential treatment for Western

\footnotetext{
${ }^{7}$ Dep't. of Homeland Security v. Regents of the Univ. of California, 140 S.Ct. 1891 (2020).
} 
Europeans was constantly asserted in battles over immigration laws. That perspective was apparent in the forced migration of African workers and in Asian exclusion laws, as well as in the anti-Southern and Eastern European quota system of the 1920s, and is maintained to this very day in the controversy over our southwest border. The Euro-centrism of the nation's identity has enabled the institutionalization of an immigration regime that commodifies those immigrants who are left out - namely, newcomers of color - into a faceless group that can more easily be demonized and even criminalized.

The process of criminalizing the immigrant and her dreams requires multiple steps. First the immigrant is dehumanized, she is then demonized and labeled a problem, then further degraded until at last her actions or conditions are criminalized. This parallels what Charles Lawrence terms "stigmatization, ... the process by which the dominant group in society differentiates itself from others by setting them apart, treating them as less than fully human, denying them acceptance by the organized community, and excluding them from participating in that community as equals" (1987).

As Professor Rhonda Magee has pointed out, the immigration system began the dehumanizing dynamics of racism with the forced migration of Black laborers called slaves (2009). Although early Chinese immigrants were welcomed with mixed greetings, eventually the anti-Chinese lobby that could not tolerate this "yellow peril" prevailed. Recruited then rejected through efforts like Operation Wetback, Mexican migrants also felt the sting of racial animus. All these groups were dehumanized through racism (Hing 2004).

The next step, identifying immigrants as a problem through demonization involves familiar allegations: they take jobs (thus the need for raids); they cost a lot; they commit crimes; they do not speak English; they damage the environment; they do not share our values; and they simply are different. This problematization-demonization process is implemented by the likes of Donald Trump, Stephen Miller, Lou Dobbs, Steve King, the Center for Immigration Studies, and the Federation of American Immigration Reform. And their tactics are successful in many quarters despite questionable empirical support for their positions. They attack with hysterical statements. While Trump and Steve King do use racial attacks, many in the anti-immigrant ranks do not mention race in their attacks and find a ready audience in members of the public (some gullible, others who themselves are racist) who look around, see immigrants with accents working, and facilely conclude that they must be taking jobs that Americans would otherwise be holding. This brand of xenophobia is recycled from the worst nativist periods of the nation's history.

After hysteria is heightened, the demonization process continues by asking the public if immigration is a problem. Modern day polls and surveys claim to reveal that if asked specifically about immigration, 80 percent of respondents think that current immigration is bad for the country. But when general polls ask respondents to name serious societal problems, immigration is either ranked low or not mentioned. Or when the public is asked whether legalization should be granted to undocumented workers and families who pay a fine, the resounding answer is yes.

Even in the midst of a robust economy, the modern problematization-demonization process has proven wildly successful. Restrictionist strategies have worked, as their proponents define the issues largely in their own terms of alleged economic and fiscal impact. Proimmigrant sentiment and immigrant rights groups essentially are silenced in the media. The media offers seat-of-the-pants economic claims that blame immigrants for job loss and wage depression in place of the more complex reality. Politicians point fingers at the disenfranchised, voiceless alien to grab the attention of voters. The media and these politicians serve as 
convenient and effective conduits for demonizing aliens. Their effectiveness is striking, as little attention is paid to the economic benefits of immigration.

As the level of demonization through anti-immigrant rhetoric reaches new heights, popular talk radio hosts, conservative columnists, and politicians, Democrats and Republicans alike, chime in. The notion of America as the land of immigrants is brushed aside. The neonativists claim that things are different today. Much of the rhetoric strikes a chord with wellmeaning, but misguided, members of the public who sense a lack of control over a variety of things that affect their lives and who are looking for simple answers. Scapegoating is in, and the blame can be dispensed in non-racial terms, using phrases like "porous" borders, "illegal" aliens, or "criminal" aliens. The framework of the visa and enforcement systems do the dirty work of exclusion and deportation of those noncitizens.

Once demonized, immigrants can be further dehumanized. Dehumanization at this stage commodifies immigrants, stripping them of race and ethnicity. The dominant group racializes the immigrant-as-commodity notion to ignore race and view the immigrant as a labor-providing commodity. This facilitates the dehumanization that follows. Like the Black-migrant commodities (enslaved African workers), the modern immigrant commodity is not treated as human. Rather, even the Supreme Court likens immigrant commodities to "hazardous waste dumps." "The Court has ruled that dangerous and hazardous materials are "commerce" subject to Commerce Clause scrutiny; and the immigrant-toxic-waste-dump commodity has little constitutional protection in this dehumanized state. Dehumanization thus silences the immigrants. Dehumanization allows the public to ignore their faces and their names. Once dehumanized, deportation is easily facilitated without asking why particular migrants come here in the first place.

Employer sanctions - the statutory provision that justifies the arrest of undocumented workers - is a major step in the dehumanization-demonization-commodification-criminalization process. Previously rejected, the employer sanctions effort was accomplished as part of IRCA in 1986. Throughout the debate, Mexican workers were largely the focal point, but they became dehumanized and commodified simply as "unauthorized" workers once sanctions were enacted (Hing 2009). The groundwork was laid for workplace raids.

\section{Structural Relationships}

Based on the manner in which immigration laws and enforcement policies have evolved, racism has been institutionalized in those laws and policies. However, writers such as john a. powell urge us to do more and to examine how different institutions interrelate with one another to produce an even more sinister dynamic. Thus, powell would encourage us to look beyond the institutionalized racism within U.S. immigration laws and enforcement policies that has become part of the "structure" of those laws and policies, and to look at the interaction between institutions for what he terms "structural racism." powell invites us to take the institution of immigration laws and policies and see how that institution relates to other institutions that can

\footnotetext{
${ }^{8}$ In INS v. Lopez-Mendoza, 468 U.S. 1032 (1984), the Supreme Court refused to extend the exclusionary rule derived from the Fourth Amendment to deportation proceedings. In the process, Justice Sandra Day O'Connor reasoned:

Presumably no one would argue that the exclusionary rule should be invoked to prevent an agency from ordering corrective action at a leaking hazardous waste dump if the evidence underlying the order had been improperly obtained, or to compel police to return contraband explosives or drugs to their owner if the contraband had been unlawfully seized.
} 
produce racial outcomes (Grant-Thomas and powell 2006).

It does not take long to realize that while immigration laws and enforcement policies have evolved in a manner that continues to prey on Mexicans, Asians, and other Latinx migrants, the relationship of those laws and policies with other racialized institutions underscores the structural challenges that immigrants of color face. Consider the North American Free Trade Agreement ("NAFTA") and the World Trade Organization ("WTO"). NAFTA placed Mexico at such a competitive disadvantage with the United States in the production of corn that Mexico now imports most of its corn from the United States, and Mexican corn farmworkers have lost their earnings. The U.S.-embraced WTO implements global free trade and favors lowest-bid manufacturing nations like China and India, so that manufacturers in a country like Mexico cannot compete and must lay off workers. Little wonder that so many Mexican workers look to the United States for jobs (Hing 2010). Think also of refugee resettlement programs as an institution. When Southeast Asian refugees are resettled in public housing or poor neighborhoods, their children find themselves in an environment that can lead to bad behavior or crime. Consider U.S. involvement in wars and civil conflict abroad. Think also of U.S. involvement in places like Vietnam, Afghanistan, or Iraq - places that have produced involuntary migrants of color to our shores. Other racialized institutions that interact with immigration laws and enforcement also come to mind: the criminal justice system, poor neighborhoods, and inner-city schools. Even coming back full circle to enslavement of people-today's human trafficking institutions--we begin to realize a sad interaction with immigration laws that requires greater attention.

The immigration admission and enforcement regimes may appear neutral on their face, but (1) they have evolved in a racialized manner and (2) when the immigration framework interacts with other racialized institutions you realize that the structure generates racial group disparities as well. NAFTA and globalization form a big part of why many migrants of color cannot remain in their native countries, and that leads to forced migration and unauthorized entry. The criminal justice system and poverty prey heavily on poor communities of color, leading to deportable offenses if defendants are not U.S. citizens. These institutions can lead to situations that spell trouble within the immigration enforcement framework, providing further foundation for workplace immigration raids.

\section{Labor Organizing as an Ingredient of Democracy}

The interference to labor organizing exemplified by raids at noncitizen worksites is an assault on democracy. The right to organize is closely related to the constitutional right to free association and assembly. In a democracy, the right of individuals to band together and pursue their interests with like-minded people is considered an essential element of freedom. Although the Constitution does not specifically mention "freedom of association," the Supreme Court long ago recognized that First Amendment free speech and freedom of assembly provisions necessarily imply a corollary right to freedom of association. ${ }^{9}$ Moreover, the Supreme Court has

9 NAACP v. Alabama, 357 U.S. 449 (1958). 
specifically applied the right of association to labor unions, striking down government efforts to quash union-based associational rights. ${ }^{10}$

Unions play a critical role in democracy. Unions decrease employers' discretion to make arbitrary and abusive decisions to fire workers or to pay some workers more than others - which can reduce opportunities for discrimination. Many Americans do not realize that most employees work "at will," meaning they can be fired for any reason or no reason at all. Unions, by contrast, usually bargain for the right to be fired only for "just cause." This higher standard for termination helps minority or female employees who are discriminated against because it is much easier to prove that a termination was unjust or arbitrary rather than having to go further and prove that it was also motivated by race or sex discrimination (Kahlenberg and Marvit 2019: $105)$.

The protections that unions provide against discrimination are especially important in low-wage jobs, where employers are more likely to act arbitrarily where women and employees of color are more likely to be concentrated, and where the low value of lost wages makes it difficult to attract an attorney for litigation on a contingency-fee basis. Plaintiffs in unionized firms are more likely to be successful with their employment discrimination suits; and they are less likely to be dismissed or to settle early. Thus, for a variety of reasons - including more uniform pay scales and the availability of grievance procedures - there appears to be "less discrimination among union workers" (Kahlenberg and Marvit 2019: 106). Guarding against unjust discrimination is an important democratic principle.

More broadly, at a time when American democracy is under tremendous stress - with attacks on the free press, an independent judiciary, and religious and racial minorities - we need a strong labor movement more than ever. Democracies need a strong middle class, and unions help create shared prosperity (Kahlenberg and Marvit 2019: 110). Civic organizations that are run democratically can also be an important mechanism for acculturating citizens to the inner workings of democracy. Unions are among the most important of these organizations, bringing together rank-and-file workers from a variety of ethnic, racial, and religious backgrounds, and serving "schools for democracy." (Putnam 2000: 80-81) Labor unions can also help create a culture of participation among workers. Being involved in workplace decisions and the give-andtake of collective bargaining, voting on union contracts, and voting for union leadership all have been called important drivers of "democratic acculturation" (Kahlenberg and Marvit 2019: 110).

Historically, unions have participated in the democratic political process, collaborating with political parties and influencing policy. They can facilitate the social compromise necessary to enact vital legislation. Politically active unions are also more likely to work within legal frameworks to resolve disputes, strengthening the government's institutional legitimacy and the rule of law. (Becker 2011)

Freedom of association and collective bargaining are crucial components of a wellfunctioning democracy. While it may seem tempting to limit the ability of organized labor's political participation - either as a means to political expediency or economic growth — such

10 Thomas v. Collins, 323 U.S. 516 (1945)I see also Smith v. Arkansas State Highway Employees Local, 441 US 463 (1979). 
actions can easily backfire, undermining the institutions for dispute resolution that are important in any well-functioning democratic society (Becker 2011).

The democratic goal of protecting civil rights also is bolstered by the labor movement. Both are concerned about the same principles: "the dignity of individuals, who have the right to be respected and valued whatever their job or race; the importance of equality, both racial and economic; the centrality of the right to vote - both for elected representatives in government and for union leadership - to bring about greater political and workplace democracy; and the salience of human solidarity, that is, the need to rise above our atomized existence to join together to improve the larger society" (Kahlenberg and Marvit 2019: 101).

\section{Conclusion}

Democracy is under attack through immigration workplace raids. Labor unions have finally come to realize that noncitizen workers - documented and undocumented - are their future. ICE raids have been timed - particularly by the Bush and Trump administrations to thwart organizing efforts. Through a process of demonizing and commodification of immigrant workers, the public has been conditioned to ignore the racial implications of ICE raids. But even a cursory examination reveals the racist effects of these enforcement efforts. However, on closer analysis reveals how these attacks are an attack on democracy as well. ICE raids are an attack on labor organizing, which in turn represents an assault on the freedom of association, freedom from discrimination, a strong middle class, and democratic acculturation. 


\section{References}

Bacon, David and Bill Ong Hing. 2010. "The Rise and Fall of Employer Sanctions," 38 Fordham Urban Law Journal 38, 1: 77-105.

Becker, Jeff. 2011. “Organized Labor's Role in Democratic Transitions," Center for American Progress, June 20, 2011. https://www.americanprogress.org/issues/security/news/2011/06/20/9744/organizedlabors-role-in-democratic-transitions/.

Budiman, Abby. 2020. "Key Findings About U.S. Immigrants," Pew Research Center (August 20, 2020). https://www.pewresearch.org/fact-tank/2020/08/20/key-findings-about-u-simmigrants/.

Bynum, Russ. 2006. “Immigration Raids Leave Georgia Town Bereft, Stunned," Seattle Times (Sept. 16, 2006).

Davidson, Joe. 2016. “Border Patrol Agents Union Endorses Trump.” Washington Post (March 30, 2016). https://www.washingtonpost.com/news/powerpost/wp/2016/03/30/borderpatrol-agents-union-endorses-trump/.

Dinan, Stephen. 2020. “Counties Eager to Cooperate With ICE as Deportation Agreements Triple," The Washington Times (June 30, 2020).

https://www.washingtontimes.com/news/2020/jun/30/ice-cooperation-surges-deportationagreements-trip/.

Elk, Mike. 2018. "Undocumented Workers Find New Ally as Unions Act to Halt Deportations," The Guardian (March 22, 2018). https://www.theguardian.com/usnews/2018/mar/22/unions-undocumented-workers-immigration-deportation-painters.

Feffer, John. 2018. “Donald Trump's War on Democracy,” The Nation (Sept. 24, 2018). https://www.thenation.com/article/archive/donald-trumps-war-on-democracy/.

Figueroa, Hector. 2019. “The Labor Movement Can Rise Again,” New York Times (July 12, 2019) https://www.nytimes.com/2019/07/12/opinion/hector-figueroa.html.

Garcia, Ruben J. 2012. Ten Years After Hoffman Plastic Compounds, Inc. v. NLRB: The Power of a Labor Law Symbol, Cornell Journal of Law \& Public Policy 21: 659 (2011-2012).

Grant-Thomas, Andrew, and john a. powell. 2006. "Toward a Structural Racism Framework," Poverty \& Race 15, 6: 3-6.

Hennelly, Bob. 2019. “There’s a Future for Organized Labor-If It Welcomes Immigrants and 
Supports Them," Salon (Sept. 1, 2019). https://www.salon.com/2019/09/01/theres-afuture-for-organized-labor-if-it-welcomes-immigrants-and-supports-them/.

Hing, Bill Ong. 2010. Ethical Borders: NAFTA, Globalization, and Mexican Migration. Philadelphia: Temple University Press.

.2009. "Institutional Racism, ICE Raids, and Immigration Reform," USF Law Review 44, 2: 307-352.

.2006. Deporting Our Souls: Values, Morality, and Immigration Policy. Cambridge, UK: Cambridge University Press.

. 2004. Defining America Through Immigration Policy. Philadelphia: Temple University Press.

Jones, Jeffrey M. 2019. “As Labor Day Turns 125, Union Approval Near 50-Year High,” Gallup, August 28, 2019. https://news.gallup.com/poll/265916/labor-day-turns-125union-approval-near-year-high.aspx

Jordan, Miriam. 2020. "After a Pandemic Pause, ICE Resumes Deportation Arrests," New York Times (Sept. 14, 2020). https://www.nytimes.com/2020/09/12/us/ice-immigration-sweepsdeportation.html\#: : text=The\%20Trump\%20administration\%20says\%20it,caught $\% 20$ up $\% 20$ in $\% 20$ immigration $\% 20$ sweeps.

Kahlenberg, Richard D, and Moshe Z. Marvit. 2019. "Making Labor Organizing a Civil Right," in Bales, Richard, and Charlotte Garden, (Eds.) 2019. The Cambridge Handbook of U.S. Labor Law for the Twenty-First Century. Cambridge, UK: Cambridge University Press.

Lawrence, Charles R. 1987. "The Id, the Ego, and Equal Protection: Reckoning with Unconscious Racism," Stanford Law Review 39, 2: 317-388.

Magee, Rhonda V. 2009. "Slavery as Immigration." University of San Francisco Law Review 44, 2: 273-306.

Milkman, Ruth. 2009. "Immigrant Workers and the Future of American Labor," ABA Journal of Labor \& Employment Law 26, 2: 295-310.

Mindock, Clark. 2018. "US Workplace Immigration Raids Surge 400\% in 2018," The Independent (Dec. 12, 2018). https://www.independent.co.uk/news/world/americas/uspolitics/ice-immigration-workplace-migrants-undocumented-immigrants-raids-trumpobama-2018-a8678746.html.

McMullin, Evan. 2018. "An Attack on the Rule of Law," The Atlantic (Apr. 13, 2018). https://www.theatlantic.com/politics/archive/2018/04/assault-on-democracy/557912/. 
Moreno, Edward. 2020. "Sally Yates Appears at Democratic Convention to Rip Trump Travel Ban,” The Hill (Aug. 18, 2020). https://thehill.com/homenews/campaign/512634-sallyyates-appears-at-democratic-convention-to-rip-trump-travel-ban.

National Commission on ICE Misconduct \& Violations of Fourth Amendment, Commission Hearing, Boston (2008) (unpublished transcript on file with author).

National Commission on ICE Misconduct \& Violations of Fourth Amendment, Commission Hearing: Des Moines, Iowa (Apr. 29, 2008) (unpublished transcript on file with author).

Newman, Jonah. 2008. Letter to the Editor, N.Y. Times (June 3, 2008)

Putnam, Robert. 2000. Bowling Alone: The Collapse and Revival of American Community. New York: Simon \& Schuster.

Pham, Huyen. 2018. “287(g) Agreements in the Trump Era," Washington \& Lee Law Review 75, 3: 1253-1286.

Preston, Julia, "Immigrant, Pregnant, Is Jailed Under Pact," N.Y. Times, July 20, 2008.

Rathod, Jayesh M. 2014. "Riding the Wave: Uplifting Labor Organization Through Immigration Reform," U.C. Irvine Law Review 4, 2: 625-654.

Rose, Joel. 2020. "Federal Court Orders Trump Administration To Accept New DACA Applications," NPR (July 17, 2020). https://www.npr.org/2020/07/17/892413311/federal-court-orders-trump-administrationto-accept-new-daca-applications.

Totenberg, Nina. 2017. "Trump's Criticism Of Judges Out of Line With Past Presidents." NPR (Feb. 11, 2017). https://www.npr.org/2017/02/11/514587731/trumps-criticism-ofjudges-out-of-line-with-past-presidents.

United Food and Commercial Workers Union. 2009. "Raids on Workers: Destroying Our Rights (2009).

Wishnie, Michael. 2004. "Introduction: The Border Crossed Us: Current Issues in Immigrant Labor," N.Y.U. Review of Law \& Social Change 28, 3: 389-395. 